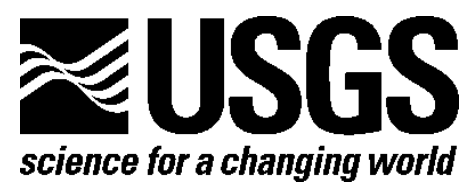

\title{
A Bioassay Assessment of a Zebra Mussel (Dreissena polymorpha) Eradication Treatment
}

By Matthew T. Barbour, Jeremy K. Wise, and James A. Luoma

Open-File Report 2018-1138

U.S. Department of the Interior

U.S. Geological Survey 


\section{U.S. Department of the Interior RYAN K. ZINKE, Secretary}

\section{U.S. Geological Survey James F. Reilly II, Director}

U.S. Geological Survey, Reston, Virginia: 2018

For more information on the USGS—-the Federal source for science about the Earth, its natural and living resources, natural hazards, and the environment-visit https://www.usgs.gov/ or call 1-888-ASK-USGS (1-888-275-8747).

For an overview of USGS information products, including maps, imagery, and publications, visit https://store.usgs.gov/.

Any use of trade, firm, or product names is for descriptive purposes only and does not imply endorsement by the U.S. Government.

Although this information product, for the most part, is in the public domain, it also may contain copyrighted materials as noted in the text. Permission to reproduce copyrighted items must be secured from the copyright owner.

Suggested citation:

Barbour, M.T., Wise, J.K., and Luoma, J.A. 2018, A bioassay assessment of a zebra mussel (Dreissena polymorpha) eradication treatment: U.S. Geological Survey Open-File Report 2018-1138, 11 p., https:// doi.org/10.3133/ofr20181138.

ISSN 2331-1258 (online) 


\section{Preface}

The purpose of this report is to disseminate the results of an onsite zebra mussel bioassay that was used as a measure of treatment efficacy during a zebra mussel eradication treatment. The early-detection and rapid-response partial-lake treatment was conducted in Lake Marion, Dakota County, Minnesota, during October 2017 with EarthTec QZ, a copper-based molluscicide. The information and data presented in this report will aid researchers, pesticide applicators, and natural resource managers in future zebra mussel eradication efforts. 


\section{Acknowledgments}

This study was part of a zebra mussel eradication project conducted by the City of Lakeville, Minnesota, the Minnesota Department of Natural Resources, and PLM Lake and Land Management Corporation (Brainerd, Minnesota). The authors thank Keegan Lund (Minnesota Department of Natural Resources) for the collection of test animals.

The authors also thank Todd J. Severson, Justin R. Smerud, and Susan M. Schleis (Upper Midwest Environmental Sciences Center) for technical assistance. 


\section{Contents}

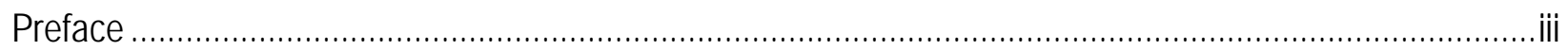

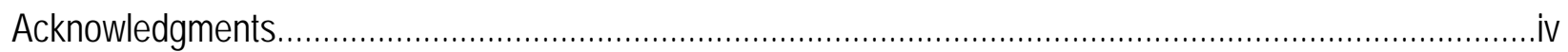

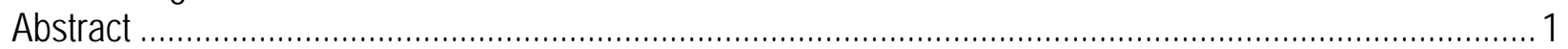

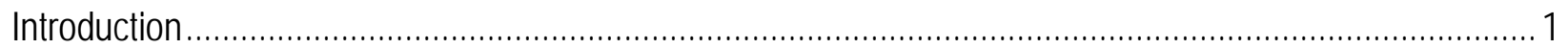

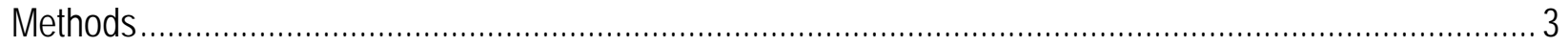

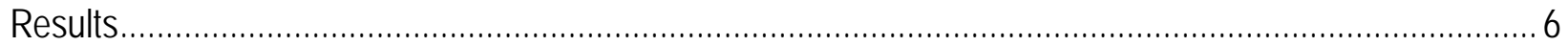

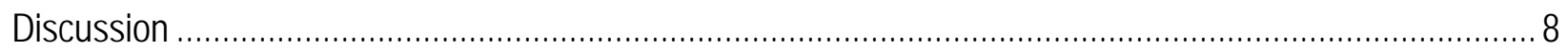

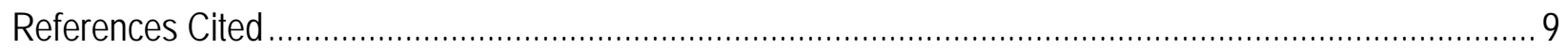

\section{Figures}

1. Map showing the study area location within Marion Lake near Lakeville, Minnesota. .................... 3

2. Photograph showing $A$, the mobile laboratory with the two head boxes and $B$, nine 350-liter test tanks that were used to complete the onsite bioassay at Marion Lake, Dakota County, Minnesota. 4

3. Graph showing copper concentration (milligrams per liter as copper [mg/L-C $\left.\mathrm{Cu}^{2+}\right]$ ) in the six treated tanks during the bioassay..... Graph showing observed bioassay mortality and predictive model for EarthTec QZ treatment at Lake Marion, Minnesota ..................................................................................................

\section{Tables}

1. Summary of water-quality parameters in three control and six treated bioassay tanks during the zebra mussel eradication treatment at Marion Lake, Dakota County, Minnesota......... 


\section{Conversion Factors}

International System of Units to Inch/Pound

\begin{tabular}{|c|c|c|}
\hline Multiply & By & To obtain \\
\hline \multicolumn{3}{|c|}{ Length } \\
\hline centimeter (cm) & 0.3937 & inch (in.) \\
\hline millimeter (mm) & 0.03937 & inch (in.) \\
\hline meter (m) & 3.281 & foot $(\mathrm{ft})$ \\
\hline meter (m) & 1.094 & yard (yd) \\
\hline \multicolumn{3}{|c|}{ Area } \\
\hline hectare (ha) & 2.471 & acre \\
\hline hectare (ha) & 0.003861 & square mile $\left(\mathrm{mi}^{2}\right)$ \\
\hline \multicolumn{3}{|c|}{ Volume } \\
\hline liter (L) & 0.2642 & gallon (gal) \\
\hline liter (L) & 61.02 & cubic inch $\left(\mathrm{in}^{3}\right)$ \\
\hline \multicolumn{3}{|c|}{ Flow rate } \\
\hline liter per minute (L/min) & 0.2642 & gallon per minute (gal/min) \\
\hline
\end{tabular}

Temperature in degrees Celsius $\left({ }^{\circ} \mathrm{C}\right)$ may be converted to degrees Fahrenheit $\left({ }^{\circ} \mathrm{F}\right)$ as ${ }^{\circ} \mathrm{F}=\left(1.8 \times{ }^{\circ} \mathrm{C}\right)+32$.

Temperature in degrees Fahrenheit $\left({ }^{\circ} \mathrm{F}\right)$ may be converted to degrees Celsius $\left({ }^{\circ} \mathrm{C}\right)$ as ${ }^{\circ} \mathrm{C}=\left({ }^{\circ} \mathrm{F}-32\right) / 1.8$.

\section{Supplemental Information}

Specific conductance is given in microsiemens per centimeter at 25 degrees Celsius $\left(\mu \mathrm{S} / \mathrm{cm}\right.$ at $\left.25^{\circ} \mathrm{C}\right)$.

Concentrations of chemical constituents in water are given in either milligrams per liter $(\mathrm{mg} / \mathrm{L})$ or micrograms per liter $(\mu \mathrm{g} / \mathrm{L})$. Note to USGS users: Use of hectare (ha) as an alternative name for square hectometer ( $\left.\mathrm{hm}^{2}\right)$ is restricted to the measurement of small land or water areas. Use of liter $(\mathrm{L})$ as a special name for cubic decimeter $\left(\mathrm{dm}^{3}\right)$ is restricted to the measurement of liquids and gases. No prefix other than milli should be used with liter.

\section{Abbreviations}

${ }^{\circ} \mathrm{C}$

$\mathrm{mg} / \mathrm{L}-\mathrm{CaCO}_{3} \quad$ milligrams per liter as calcium carbonate

$\mathrm{mg} / \mathrm{L}-\mathrm{Cu}^{2+} \quad$ milligrams per liter as copper

$\mathrm{mm} \quad$ millimeter

EPA U.S. Environmental Protection Agency 


\title{
A Bioassay Assessment of a Zebra Mussel (Dreissena polymorpha) Eradication Treatment
}

\author{
By Matthew T. Barbour, Jeremy K. Wise, and James A. Luoma
}

\begin{abstract}
Zebra mussels (Dreissena polymorpha, Pallas, 1771) are an aquatic invasive species in the United States, and new infestations of zebra mussels can rapidly expand into dense colonies. Zebra mussels were first reported in Marion Lake, Dakota County, Minnesota, in September 2017, and surveys indicated the infestation was likely isolated near a public boat access. A 2.4-hectare area containing the known zebra mussel infestation was enclosed and treated by area resource managers for 9 days with EarthTec QZ (target concentration: 0.5 milligrams per liter as copper), a copper-based molluscicide, to eradicate the zebra mussels. Researchers led an onsite bioassay to provide an estimate of the treatment efficacy within the enclosure. The bioassay was conducted in a mobile assay trailer that received a continuous flow of treated lake water. Bioassay tanks ( $n=9 ; 350$ liters) within the trailer were stocked with zebra mussels (25 mussels per containment bag; 7 bags per tank) collected from White Bear Lake, Ramsey County, Minn. Mortality in the treated bioassay tanks reached a mean of 99 percent (95-percent confidence interval: 98-100 percent), there were no mortalities in the control tanks. However, a predictive model produced for timely delivery to area resource managers indicated zebra mussel mortality within the treated enclosure may have been as low as 85 percent. Onsite bioassays are a viable and important tool for treatment evaluation particularly in newly infested waterbodies with low zebra mussel densities.
\end{abstract}

\section{Introduction}

Zebra mussels (Dreissena polymorpha, Pallas, 1771) are a prolific aquatic invasive species that have spread across much of North America since their introduction into the Laurentian Great Lakes during the mid-1980s (Benson, 2013). The invasion of zebra mussels continues into inland waterways via anthropogenic means (Johnson and Carlton, 1996; Johnson and others, 2001; Kelly and others, 2013). Once introduced, zebra mussels can quickly spread throughout a newly infested waterbody due to their high fecundity, planktonic veliger stage, and rapid maturation, which causes a multitude of ecological and economic problems (Griffiths and others, 1991; Johnson and Carlton, 1996; Keller and others, 2007). For example, zebra mussels can greatly alter the aquatic food web by shifting the ecosystem's energy dynamics (Griffiths and others, 1991; Fanslow and others, 1995; Johnson and Carlton, 1996; Strayer, 2009). Filter feeding activity of zebra mussel populations have been observed to diminish phytoplankton and zooplankton communities, which negatively impacts native bivalves and fish populations (Strayer and others, 1999; Higgins and Zanden, 2010). Native freshwater bivalves (Unionidae) are one of the most heavily impacted fauna groups in North America since the arrival of the zebra mussel (Schloesser and others, 1996; Ricciardi and others, 1998; Strayer and others, 2004; Schloesser and others, 2006). In addition, zebra mussels and quagga mussels (Dreissena bugensis, 
Andrusov, 1897; collectively referred to as Dreissenid mussels) are notorious for their biofouling capabilities that have caused damages to industry, commerce, and recreation costing in excess of \$100 million annually in remediation (Connelly and others, 2007; Strayer, 2009).

Eradication and control of zebra mussel populations in whole waterbodies has had limited success. The only known success for complete eradication of an established zebra mussel population throughout an entire waterbody occurred at Millbrook Quarry Lake (4.9 hectare [ha]; Prince William County, Virginia). A 3-week treatment of potassium chloride with a target of 100 milligrams per liter as potassium eradicated zebra mussels with minimal non-target consequences, although non-target species populations may have been low to begin with (Fernald and Watson, 2013). The successful eradication at Millbrook Quarry Lake was primarily attributed to hydrologic isolation, which allowed lethal concentrations to be maintained even 2 years after the treatments and limited public access to the waterbody preventing the reintroduction of zebra mussels. Hydrologic isolation is not typical of many waterbodies susceptible to zebra mussel infestation, and connectivity to other infested waterbodies can impede long-term eradication success. Eradication treatments at Lake Offut (also known as Base Lake; 46.5 ha; Sarpy County, Nebraska) killed all adult zebra mussels and planktonic veligers after two whole lake applications of copper sulfate, in 2008 and 2009, with a target of 1 milligrams per liter as copper (mg/L-Cu2+); however, the treatments also induced a significant non-target fish kill (URS Inc., 2009). Zebra mussels were rediscovered in the lake in 2014 despite the lake outlets being sealed after the initial discovery of zebra mussels which effectively isolated the lake hydrologically (URS Inc., 2009; Zach, 2018). Further efforts to control the population since reinfestation have included the introduction and stocking of zebra mussel predators (for example, redear sunfish [Lepomis microlophus, Guenther, 1859]) and regular zebra mussel population monitoring (Zach, 2018). A partial-lake eradication was attempted in Christmas Lake (265 ha; Hennepin County, Minnesota, using three molluscicides (Zequanox, copper, and potash) applied separately during a 3-month period within enclosures (0.02 to 4.1 ha; Lund and others, 2017). Unfortunately, live adult zebra mussels were identified outside of the treatment areas a year after the otherwise successful treatments, which highlights some of the limitations to partial-lake treatments and the importance of accurate pretreatment surveys (Lund and others, 2017).

EarthTec QZ is a U.S. Environmental Protection Agency (EPA)-registered, copper-based molluscicide for dreissenid mussel control in openwaters. Factors that affect the toxicity and bioavailability of copper include alkalinity, water hardness, $\mathrm{pH}$, and organic matter (Kiaune and Singhasemanon, 2011; Meador, 1991; Santore and others, 2001; Sciera and others, 2004). Temperature has been demonstrated to be a significant factor in the sensitivity of zebra mussels to copper (Costa and others, 2008; Luoma and others, in press; Rao and Khan, 2000).

Resource managers initiated a rapid-response protocol when zebra mussels were discovered in Marion Lake (226.6 ha, Dakota County, Minn.) during September 2017. Initial surveys, conducted by area resource managers, indicated that the infestation was likely isolated near the public boat access (McComas, written commun.; Lund and Londo, written commun.). A total of 19 zebra mussels (shell length 7-26 millimeters [mm]) were present within a 0.2 ha area around a public boat access (Lund and Londo, written commun.). On October 10, 2017, area resource managers initiated a 9-day, partial lake treatment with EarthTec QZ in an attempt to eradicate zebra mussels within the infested area near a public boat access. The zebra mussel eradication treatment at Marion Lake provided an opportunity to complete an onsite confirmation bioassay for monitoring treatment efficacy, the objective of this study. Results of this study and future efficacy confirmation bioassays will provide critical data to aquatic resource managers engaged in zebra mussel treatments using copper-based products. 


\section{Methods}

Researchers conducted an onsite bioassay in an enclosed trailer adjacent to the treatment area at Marion Lake near Lakeville, Minnesota. Marion Lake is a 226.6-ha lake with a maximum depth of 5.5 meters located near Lakeville, Minn., Dakota County. During the treatment applications, an impermeable turbidity barrier was used to enclose the 2.4-ha treatment area $\left(44^{\circ} 39^{\prime} 59.7^{\prime \prime} \mathrm{N}\right.$ $93^{\circ} 17^{\prime} 05.9^{\prime \prime} \mathrm{W}$ ), which had a maximum depth of 2.7 meters (fig. 1 ). The public boat access, located within the treated area, was closed during the treatment to prevent disturbance.

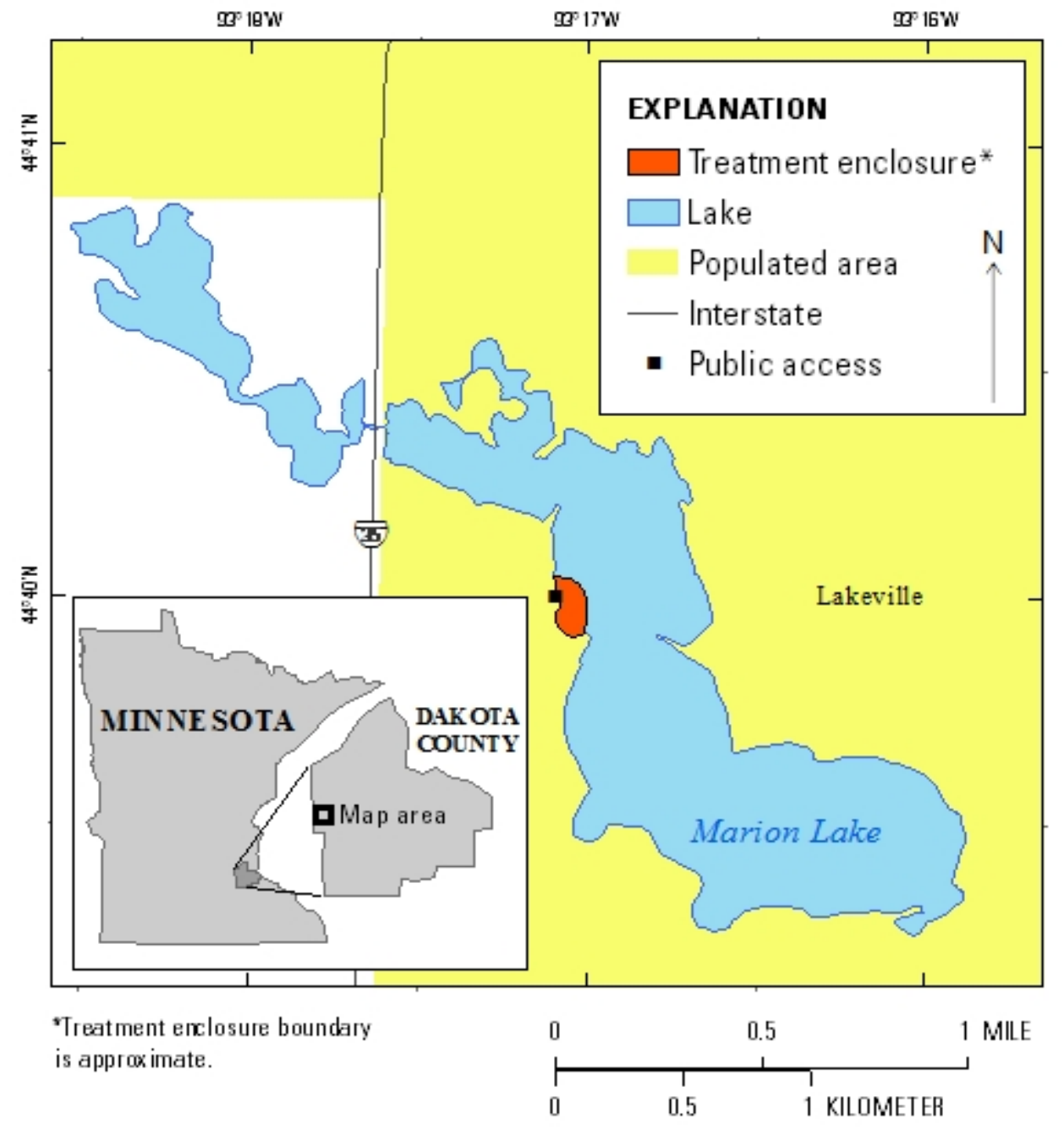

Figure 1. Map showing the study area location within Marion Lake near Lakeville, Minnesota.

Due to low zebra mussel densities in Marion Lake, mussels for the bioassay were collected from White Bear Lake, Ramsey County, Minn., and transported in coolers to the test location by personnel from the Minnesota Department of Natural Resources. Mussels were removed from rocks and woody debris from the collection site by severing their byssal threads with a scalpel and were evaluated for suitability by challenging their adductor muscle. The condition of each test animal was evaluated by applying gentle pressure to open the valves of the mussels; the mussels exhibiting a weak response were rejected from the assay. A day prior to the first EarthTec QZ treatment application, mussels ( $n=25$; 
mean shell length: 13.8-mm, range: $8.6-20.7 \mathrm{~mm}$ ) were indiscriminately selected and placed into plastic, non-wicketed mesh bags (containment bag; Hubert Company, Harrison, Ohio) that were held open at the bottom with a polyvinyl chloride pipe ring ( 10 by 2.5 centimeters; diameter by height) and tied closed at the top after the addition of the mussels. Seven containment bags with zebra mussels were indiscriminately placed into each of the 9 bioassay tanks for a total of 63 bags. After the termination of the bioassay, a representative group of control mussels $(n=200)$ were preserved in 70 -percent isopropanol, and shell lengths were individually measured with a digital caliper (Mitutoyo American Corporation, Aurora, Illinois; model: CD-6” ASX).

The onsite bioassay system consisted of nine 350-liter circular tanks installed in an enclosed trailer (fig. 2). A 3-horsepower submersible well pump (ITT Goulds Pumps, Seneca Falls, New York; model: 18GS30), suspended in the water column within a caged float, delivered water from the treatment enclosure to two head boxes within the trailer ( 135.5 liter each). The head boxes continuously supplied treated lake water to six tanks at a rate of one tank exchange per hour ( $\sim 6$ liters per minute). Effluent from the treated tanks was returned to the treatment area in the lake. The remaining three tanks were static-renewal control tanks. One-half of the water in each control tank was exchanged daily with untreated lake water. Water removed from the control tanks was discharged onto the ground away from the lake to prevent potential reintroduction of zebra mussel veligers.

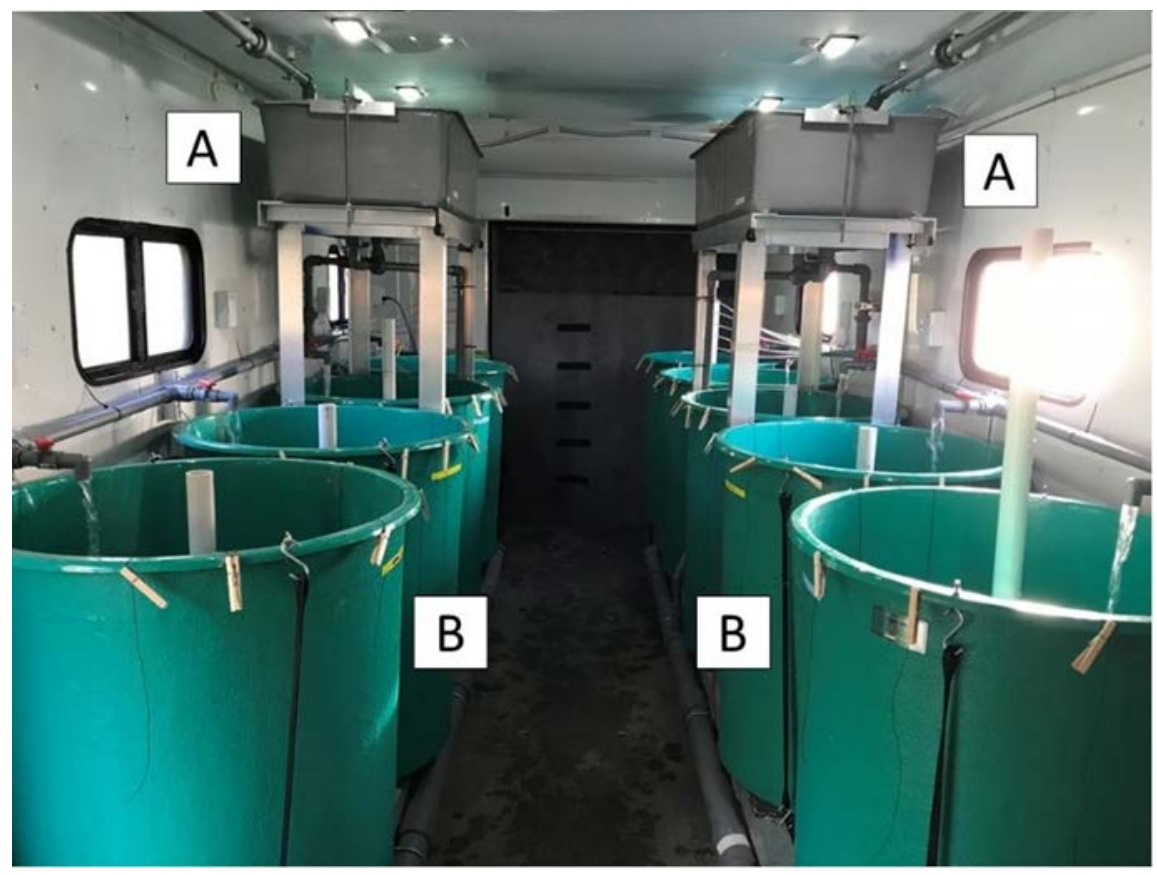

Figure 2. Photograph showing $A$, the mobile laboratory with the two head boxes and $B$, nine 350 -liter test tanks that were used to complete the onsite bioassay at Marion Lake, Dakota County, Minnesota.

EarthTec QZ applications within the treatment enclosure were conducted by PLM Lake and Land Management Corporation (PLM; Brainerd, Minn.) during a 9-day period (October 10-18, 2017, day 0-8, respectfully) with an overall mean target of $0.5 \mathrm{mg} / \mathrm{L}-\mathrm{Cu}^{2+}$. EarthTec QZ was applied by PLM daily with dose spikes applied the first 3 days and the last day of the treatment period (that is days 0-2 and day 8). The treatment barriers were removed 2 days after the last EarthTec QZ application.

Waterflow from the lake enclosure to the treated bioassay tanks was initiated 1 day prior to treatment initiation and was continuous thereafter. Water samples were collected daily from each bioassay tank to verify copper concentration. Samples were filtered through a 0.45-micrometer nylon 
syringe filter (VWR, Radnor, Pennsylvania; catalog number: 28145-485), acidified with nitric acid (1percent by volume), and stored in the dark until analysis. Copper concentrations were determined with a Microwave Plasma Atomic Emission Spectrometer (MP-AES; Agilent Technologies, Santa Clara, California; model: 4100) at a wavelength of 324.75 nanometers, and concentrations were determined by comparison to a five-point quadratic-regression standard curve created with analytical standards that bracketed the target concentration.

Water quality was assessed daily in each bioassay tank (table 1). Dissolved oxygen, in milligrams per liter (mg/L), and $\mathrm{pH}$ were measured with a multi-parameter meter (Hach Company, Loveland, Colorado; model: HQ40d) equipped with a luminescent dissolved oxygen probe (Hach Company; model: LDO101) and a refillable glass pH probe (Hach Company; model: PHC705). Temperature, in degrees Celsius $\left({ }^{\circ} \mathrm{C}\right)$, was measured using a digital thermometer (ThermoWorks, American Fork, Utah; model: Thermapen Mk4). Specific conductance, in microsiemens per centimeter at $25^{\circ} \mathrm{C}$, was measured with an Accumet model AP75 conductivity meter fitted with an automated temperature compensating probe (Fisher Scientific, Hampton, New Hampshire). Alkalinity, in milligrams per liter as calcium carbonate $\left(\mathrm{mg} / \mathrm{L}-\mathrm{CaCO}_{3}\right)$, was measured in representative control and treated tanks by titrating to an endpoint of pH 4.5 (American Public Health Association and others, 2012; method 2320 B).

Table 1. Summary of water-quality parameters in three control and six treated bioassay tanks during the zebra mussel eradication treatment at Marion Lake, Dakota County, Minnesota.

[n, number of samples; SD, standard deviation; ${ }^{\circ} \mathrm{C}$, degrees Celsius; mg/L, milligrams per liter]

\begin{tabular}{|c|c|c|c|c|c|}
\hline $\begin{array}{l}\text { Treatment } \\
\text { group }\end{array}$ & $\mathrm{n}$ & Mean & (SD) & Minimum & Maximum \\
\hline \multicolumn{6}{|c|}{ Temperature $\left({ }^{\circ} \mathrm{C}\right)$} \\
\hline Control & 33 & 15.4 & $(1.15)$ & 13.9 & 17.6 \\
\hline Treated & 66 & 13.3 & $(0.663)$ & 12.4 & 14.5 \\
\hline \multicolumn{6}{|c|}{ Dissolved oxygen (mg/L) } \\
\hline Control & 33 & 8.86 & $(0.589)$ & 7.99 & 10.21 \\
\hline Treated & 66 & 8.76 & $(0.541)$ & 7.91 & 10.04 \\
\hline \multicolumn{6}{|c|}{$\mathrm{pH}$} \\
\hline Control & 33 & 8.25 & $(0.0766)$ & 8.09 & 8.37 \\
\hline Treated & 66 & 8.12 & $(0.141)$ & 7.91 & 8.38 \\
\hline \multicolumn{6}{|c|}{ Specific conductance (microsiemens per centimeter at $25^{\circ} \mathrm{C}$ ) } \\
\hline Control & 33 & 509 & $(29.8)$ & 457 & 575 \\
\hline Treated & 66 & 511 & $(31.1)$ & 455 & 581 \\
\hline \multicolumn{6}{|c|}{ Alkalinity (mg/L as calcium carbonate) } \\
\hline Control & 11 & 178 & $(5.20)$ & 172 & 188 \\
\hline Treated & 11 & 181 & $(6.62)$ & 174 & 192 \\
\hline \multicolumn{6}{|c|}{ Hardness (mg/L as calcium carbonate) } \\
\hline Control & 10 & 137 & $(3.05)$ & 130 & 140 \\
\hline Treated & 10 & 137 & $(3.95)$ & 127 & 141 \\
\hline
\end{tabular}


Treatment efficacy was assessed by observing zebra mussel mortality within the bioassay containment bags. Daily mortality assessments began approximately 48 hours after treatment initiation. One containment bag from every bioassay tank was removed daily, and mussel mortality was evaluated by the lack of adductor muscle resistance to gentle valve pressure or failure to close valves after gentle prodding. Mussels were not returned to the tanks after the assessment for days 2-6. The assessment scheme was changed beginning on day 7 to lengthen the bioassay due to a lack of complete mortality in the treated bioassay tanks. Living mussels from the assessment on day 7 were returned to their respective tanks. Mussel mortality was assessed in both of the remaining bags in each bioassay tank (two bags per tank) for the remainder of the study. The new scheme observed cumulative mortality for days 8-10, whereby dead mussels were discarded and live mussels were returned to their respective bioassay tank.

A predictive model of zebra mussel mortality within the treated enclosure was generated using a log-logistic cumulative distribution function on the bioassay mortality data (SigmaPlot, Version 14.0). Water-chemistry parameters and copper concentrations were summarized with descriptive statistics. The individual tanks were the experimental units for all analyses. Zebra mussel mortality (mean percentage) was summarized by day for days 2-6 and reported as cumulative mortality for days 8-10.

\section{Results}

All water-quality parameters during the bioassay were within acceptable criteria for aquaculture (table 1; Timmons and Ebeling, 2013). Minimal differences were observed in water-quality parameters between the treated and control tanks. Water temperature in the control tanks ranged from 13.9 to $17.6^{\circ} \mathrm{C}\left(15.4 \pm 1.2^{\circ} \mathrm{C}\right.$; mean \pm standard deviation) and was slightly higher than the treated group, which ranged from 12.4 to $14.5^{\circ} \mathrm{C}\left(13.3 \pm 0.7^{\circ} \mathrm{C}\right)$. This difference in temperature is likely attributed to the ambient warming of the static-renewal control tanks, compared to the continuous flowthrough in the treated tanks. Dissolved oxygen stayed above $7.90 \mathrm{mg} / \mathrm{L}$ in all tanks, and individual $\mathrm{pH}$ measurements ranged from 7.91 to 8.38. Specific conductance ranged from 455 to 581 microsiemens per centimeter at $25^{\circ} \mathrm{C}$ during the bioassay. Alkalinity and total hardness ranged from 172 to 192 and 127 to $141 \mathrm{mg} / \mathrm{L}-$ $\mathrm{CaCO}_{3}$, respectfully.

Copper concentrations in the treated tanks were far below the maximum concentration specified on the EarthTec QZ label (1.0 mg/L-Cu ${ }^{2+}$; U.S. Environmental Protection Agency, 2015). Daily copper

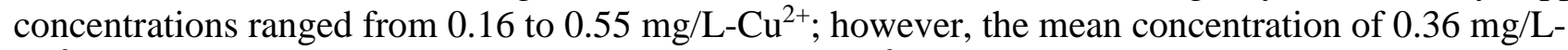
$\mathrm{Cu}^{2+}$ was below the target concentration of $0.5 \mathrm{mg} / \mathrm{L}-\mathrm{Cu}^{2+}$ (fig. 3). Analyses of water from control-tank replicates indicated that background copper concentrations were less than $0.01 \mathrm{mg} / \mathrm{L}_{-} \mathrm{Cu}^{2+}$ during the bioassay. 


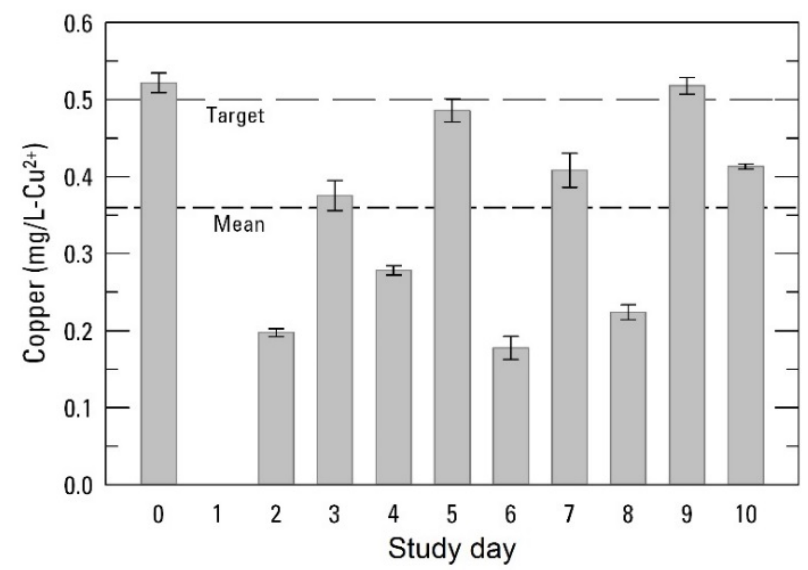

Figure 3. Graph showing copper concentration (milligrams per liter as copper [mg/L-Cu$\left.{ }^{2+}\right]$ ) in the six treated tanks during the bioassay. Error bars represent 95-percent confidence intervals. The dashed reference line represents the target concentration $\left(0.5 \mathrm{mg} / \mathrm{L}-\mathrm{Cu}^{2+}\right)$, and the dotted reference line represents the overall treatment mean concentration $\left(0.36 \pm 0.13 \mathrm{mg} / \mathrm{L}-\mathrm{Cu}^{2+} ; \bar{x} \pm \mathrm{SD}\right)$. EarthTec QZ applications were made daily starting on treatment day 0 , with the last application on study day 8 . No samples were collected on study day 1.

Mean zebra mussel mortality in treated tanks increased with time and reached a maximum observed mortality of 99 percent (95-percent confidence interval: 98-100 percent) by the final day of the bioassay (fig. 4). There was no control mortality during the bioassay. The non-linear prediction model was more conservative than the observed mortality and suggested that the mortality within the lake enclosure was between 85 and 100 percent (adjusted $\mathrm{R}^{2}=0.9700, p<0.001$; fig. 4; appendix). Mean mussel shell length was $13.8 \mathrm{~mm}$ (range: 8.6-20.7 mm).

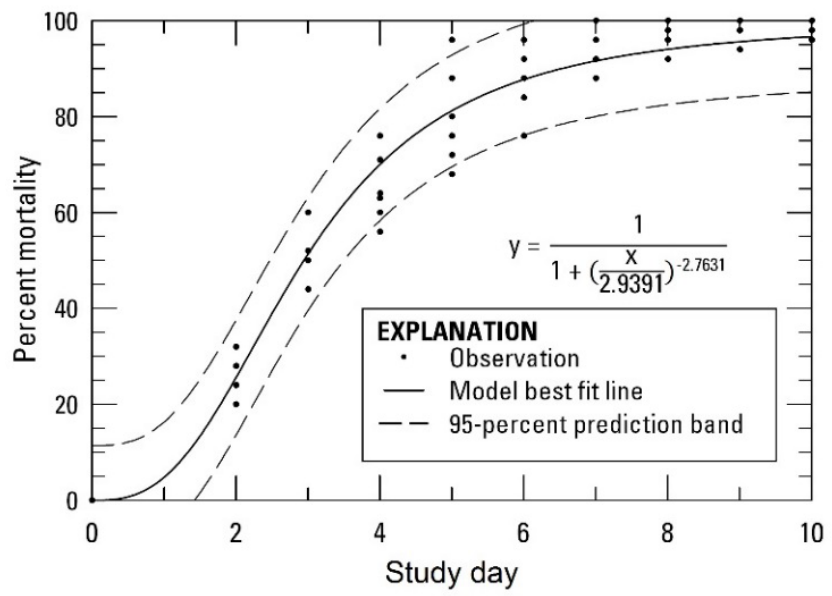

Figure 4. Graph showing observed bioassay mortality and predictive model for EarthTec QZ treatment at Lake Marion, Minnesota. Treatment applications were made daily starting on treatment day 0 and ending on treatment day 8. Mortality assessments were made starting on treatment day 2 and ending on day 10 . The log-logistic regression model suggests the treatment induced between 85 and 100-percent mortality (adjusted $R^{2}=0.9700 ; F_{(2 \text {, }}$ $\left.\left.{ }_{58}\right)=5416.485 ; p<0.001\right)$ within the treated lake enclosure. 


\section{Discussion}

Although the researchers did not observe 100-percent mortality in this bioassay assessment, EarthTec QZ is still an effective tool for zebra mussel control as determined in previous eradications at Base Lake and Christmas Lake. Treatments at Base Lake successfully eradicated zebra mussels, both adults and veligers, but ultimately the lake was reinfested from an outside source (URS Inc., 2009; Zach, 2018). Post-treatment assessments at Christmas Lake also indicated complete eradication; however, there was infestation outside of the treated area revealed during lake surveys (Lund and others, 2017). The observed mortality and predictive model for our bioassay may underestimate the true mortality within the lake enclosure considering that we did not assess delayed mortality beyond 2 days after the treatments halted and have limited statistical power in the model due to limited observations. Establishment of a standardized protocol for zebra mussel eradication bioassays, to include posttreatment observation periods, would only serve to strengthen the results and confidence of the bioassays.

The duration of the post-treatment observation period should take into consideration variables known to affect the efficacy of copper treatments. Increasing temperature is known to increase copper toxicity for zebra mussels (Luoma and others, in press). Luoma and others (2017) recommended the use of a modified temperature-unit based system, similar to that described by Piper and others (1986) for hatchery operations, in determining the length of post-exposure observation periods to account for delayed mortality. Luoma and others (2017) assigned a temperature unit for each degree Celsius during a 24-hour period (for example, 15 temperature units would be assigned for each 24-hour period at $15^{\circ} \mathrm{C}$ ) and established a holding period of 150 temperature units (for example, 10 days using the previous example) to account for zebra mussel delayed mortality. The efficacy of copper treatments can also be affected by alkalinity, water hardness, $\mathrm{pH}$, and organic matter which all affect the amount of biologically available copper (Meador, 1991; Santore and others, 2001; Sciera and others, 2004; Kiaune and Singhasemanon, 2011). The EPA's biotic ligand model is a valuable tool that takes into account temperature, alkalinity, dissolved organic carbon, $\mathrm{pH}$, humic acid, sulfate, and the following dissolved ions: calcium, magnesium, sodium, potassium, and chloride. The use of this established model would provide another means to compare results from treatments by accurately determining the amount of biologically available copper (Paquin and others, 2000). Macrophyte biomass and sediment type can also affect copper concentrations in the water column during treatments, although assessing their impacts proves difficult (Kiaune and Singhasemanon, 2011). Sampling treated water more frequently is imperative for the analysis of biologically available copper throughout a treatment, and the standardization of a sampling schema would further serve as a means of comparison among different treatments.

A potential confounding factor associated with this study was the use of zebra mussels from an alternative source location. Zebra mussels from a different source population are often required for use in bioassay assessments given their low density within a newly infested waterbody. Differences in health and condition among mussels used in the bioassay and the targeted mussel population is of particular concern. Nalepa and others (1993) discussed the seasonal and annual variations in factors attributed to zebra mussel condition. Nalepa and others (1993) discussed seasonal fluctuation in body mass attributed to phytoplankton availability and reproductive cycle. Hincks and Mackie (1997) determined that various water-quality parameters (for example, $\mathrm{pH}$, alkalinity, and chlorophyll) are highly correlated with zebra mussel health. Hincks and Mackie (1997) also determined that zebra mussel populations in waterbodies with more chlorophyll and higher alkalinity support larger and healthier populations (that is less mortality and faster growth). Aldridge and others (2004) speculated that zebra mussels from different populations may be adapted to the specific environmental parameters 
within their respectful waterbodies. Use of healthy mussels from waters with similar water-quality characteristics is paramount to providing an accurate treatment efficacy assessment.

Bioassays serve an important function in eradication efforts by giving applicators and resource managers a means to assess efficacy and estimate in situ mortality. Combining these bioassay results with multiple post-treatment efficacy monitoring techniques (for example, physical surveys for adults, plankton tows for veligers, and eDNA sampling for possible presence) creates a more comprehensive evaluation of treatment efficacy and could identify the need for further treatment (Fernald and Watson, 2013; Lund and others, 2017; URS Inc., 2009). Increased sampling frequency for molluscicide concentration to better capture fluctuations in concentration and the collection of the water-quality input parameters required by the EPA's Biotic Ligand Model would aid in the transferability of the results from copper-based molluscicide treatments to future treatments.

\section{References Cited}

Aldridge, D.C., Elliott, P., and Moggridge, G.D., 2004, The recent and rapid spread of the zebra mussel (Dreissena polymorpha) in Great Britain: Biological Conservation, v. 119, no. 2, p. 253-261.

American Public Health Association, American Water Works Association, and Water Environment Federation, 2012, Standard methods for the examination of water and wastewater: American Public Health Association, Washington, D.C., 1426 p.

Benson, A.J., 2013, Chronological history of zebra and quagga mussels (Dreissenidae) in North America, 1988-2010, in Nalepa, T.F., and Schloesser, D.W., eds., Quagga and zebra musselsBiology, impacts, and controls: Boca Raton, Fla., CRC Press.

Connelly, N.A.; O’Neill, C.R., Jr.; Knuth, B.A.; and Brown, T.L., 2007, Economic impacts of zebra mussels on drinking water treatment and electric power generation facilities: Environmental Management, v. 40, no. 1, p. 105-112.

Costa, R., Aldridge, D.C., and Moggridge, G.D., 2008, Seasonal variation of zebra mussel susceptibility to molluscicidal agents: Journal of Applied Ecology, v. 45, no. 6, p. 1712-1721.

Fanslow, D.L., Nalepa, T.F., and Lang, G.A., 1995, Filtration rates of the zebra mussel (Dreissena polymorpha) on natural seston from Saginaw Bay, Lake Huron: Journal of Great Lakes Research, v. 21, no. 4, p. 489-500.

Fernald, R.T., and Watson, B.T., 2013, Eradication of zebra mussels (Dreissena polymorpha) from Millbrook quarry, Virginia, in Nalepa, T.F., and Schloesser, D.W., eds., Quagga and zebra musselsBiology, impacts, and controls: Boca Raton, FL, CRC Press.

Griffiths, R.W., Schloesser, D.W., Leach, J.H., and Kovalak, W.P., 1991, Distribution and dispersal of the zebra mussel (Dreissena polymorpha) in the Great Lakes region: Canadian Journal of Fisheries and Aquatic Sciences, v. 48, no. 8, p. 1381-1388.

Higgins, S.N., and Zanden, M.J.V., 2010, What a difference a species makes-A meta-analysis of dreissenid mussel impacts on freshwater ecosystems: Ecological Monographs, v. 80, no. 2, p. 179_ 196.

Hincks, S.S., and Mackie, G.L., 1997, The Zebra mussel, Dreissena polymorpha-A synthesis of European experiences and a preview for North America: Canadian Journal of Fisheries and Aquatic Sciences, v. 54, p. 2049-2057.

Johnson, L.E., and Carlton, J.T., 1996, Post-establishment spread in large-scale invasions-Dispersal mechanisms of the zebra mussel Dreissena polymorpha: Ecology, v. 77, no. 6, p. 1686-1690.

Johnson, L.E., Ricciardi, A., and Carlton, J.T., 2001, Overland dispersal of aquatic invasive species-A risk assessment of transient recreational boating: Ecological Applications, v. 11, no. 6, p. 1789-1799. 
Keller, R.P., Drake, J.M., and Lodge, D.M., 2007, Fecundity as a basis for risk assessment on nonindigenous freshwater molluscs: Conservation Biology, v. 21, no. 1, p. 191-200.

Kelly, N.E., Wantola, K., Weisz, E., and Yan, N.D., 2013, Recreational boats as a vector of secondary spread for aquatic invasive species and native crustacean zooplankton: Biological Invasions, v. 15, no. 3, p. 509-519.

Kiaune, L., and Singhasemanon, N., 2011, Pesticidal copper (I) oxide-Environmental fate and aquatic toxicity, in Whitacre, D.M., ed., Reviews of environmental contamination and toxicology volume 213: New York, Springer, p. 1-26.

Lund, K., Cattoor, K.B., Fieldseth, E., Sweet, J., and McCartney, M.A., 2017, Zebra mussel (Dreissena polymorpha) eradication efforts in Christmas Lake, Minnesota: Lake and Reservoir Management, v. 34, p. 7-20.

Luoma, J.A., Dean, J.C., Severson, T.J., Wise, J.K., and Barbour, M.T., 2017, Use of alternating and pulse direct current electrical fields for zebra mussel control: Management of Biological Invasions, v. 8, no. 3, p. 311-324.

Luoma, J.A., Severson, T.J., Barbour, M.T., and Wise, J.K., in press, Determination of potential limitedscale, rapid-response zebra mussel (Dreissena polymorpha) eradication treatments by evaluating the influences of temperature and exposure duration on toxicant potency: Management of Biological Invasions, v. 9.

Meador, J.P., 1991, The interaction of $\mathrm{pH}$, dissolved organic carbon, and total copper in the determination of ionic copper and toxicity: Aquatic Toxicology, v. 19, no. 1, p. 13-32.

Nalepa, T.F., Cavaletto, J.F., Ford, M., Gordon, W.M., and Wimmer, M., 1993, Seasonal and annual variation in weight and biochemical content of the zebra mussel, Dreissena polymorpha, in Lake St. Clair: Journal of Great Lakes Research, v. 19, no. 3, p. 541-552.

Paquin, P.R., Santore, R.C., Wu, K.B., Kavvadas, C.D., and Di Toro, D.M., 2000, The biotic ligand model-A model of the acute toxicity of metals to aquatic life: Environmental Science \& Policy, v. 3, p. 175-182.

Piper, R.G., McElwain, I.B., Orme, L.E., McCraren, J.P., Fowler, L.G., and Leonard, J.R., 1986, Fish hatchery management: Washington, D.C., United States Department of the Interior, Fish and Wildlife Service, $517 \mathrm{p}$.

Rao, D.G.V., and Khan, M.A.Q., 2000, Zebra mussels-Enhancement of copper toxicity by high temperature and its relationship with respiration and metabolism: Water Environment Research, v. 72, no. 2, p. 175-178.

Ricciardi, A., Neves, R.J., and Rasmussen, J.B., 1998, Impending extinctions of North American freshwater mussels (Unionoida) following the zebra mussel (Dreissena polymorpha) invasion: Journal of Animal Ecology, v. 67, no. 4, p. 613-619.

Santore, R.C., Di Toro, D.M., Paquin, P.R., Allen, H.E., and Meyer, J.S., 2001, Biotic ligand model of the acute toxicity of metals. 2. Application to acute copper toxicity in freshwater fish and Daphnia: Environmental Toxicology and Chemistry, v. 20, no. 10, p. 2397-2402.

Schloesser, D.W., Metcalfe-Smith, J.L., Kovalak, W.P., Longton, G.D., and Smithee, R.D., 2006, Extirpation of freshwater mussels (Bivalvia-Unionidae) following the invasion of dreissenid mussels in an interconnecting river of the Laurentian Great Lakes: American Midland Naturalist, v. 155, no. 2, p. 307-320.

Schloesser, D.W., Nalepa, T.F., and Mackie, G.L., 1996, Zebra mussel infestation of unionid bivalves (Unionidae) in North America: American Zoologist, v. 36, no. 3, p. 300-310. 
Sciera, K.L., Isely, J.J., Tomasso, J.R., and Klaine, S.J., 2004, Influence of multiple water-quality characteristics on copper toxicity to fathead minnows (Pimephales promelas): Environmental Toxicology and Chemistry, v. 23, no. 12, p. 2900-2905.

Strayer, D.L., 2009, Twenty years of zebra mussels-Lessons from the mollusk that made headlines: Frontiers in Ecology and the Environment, v. 7, no. 3, p. 135-141.

Strayer, D.L., Caraco, N.F., Cole, J.J., Findlay, S., and Pace, M.L., 1999, Transformation of freshwater ecosystems by bivavles-A case study of zebra mussels in the Hudson River: Bioscience, v. 49, no. 1, p. 19-27.

Strayer, D.L., Downing, J.A., Haag, W.R., King, T.L., Layzer, J.B., Newton, T.J., and Nichols, S.J., 2004, Changing perspectives on pearly mussels, North America's most imperiled animals:

Bioscience, v. 54, no. 5, p. 429.

Timmons, M.B., and Ebeling, J.M., 2013, Recirculating aquaculture (3d ed.): Ithaca, N.Y., Ithaca Publishing Company, LLC, 788 p.

URS Inc, 2009, Zebra mussel eradication project: 55 CES/CEV, 51 p.

U.S. Environmental Protection Agency, 2015, Master label for earthtec: EPA Reg. No. 64962-1. Zach, A., 2018, Nebraska zebra mussel case studies, in webinar, Case studies in response to and management of invasive mussel infestations: Invasive Mussel Collaborative, accessed July 13, 2018, at https://invasivemusselcollaborative.net/2018/01/11/webinar-case-studies-in-response-to-andmanagement-of-invasive-mussel-infestations/. 